season is expected to show a reduction in South Africa, Australia, and New Zealand, and although there may be slight increases in South America, the United States, and Great Britain, the aggregate production of these countries will probably be about 7 per cent less than last year. The increase in prices reflects not only this reduced production but also a real increase in consumption in all the world's textile centres. Along with this, unemployment in the woollen and worsted trades in Great Britain is down to 8 per cent, a half of what it was a year ago. The report gives details of wool trade and manufacture in many countries, mentioning some interesting developments. For example, "Active steps are being taken, with Japanese co-operation, to encourage sheep-raising and wool production in Manchuria with the object of securing for Japan an alternative source of supply" (most of her wool at present coming from Australia). Recovery in the mohair industry is also reported; the development of Empire trade may be seen in the imports into Great Britain, almost all of which now come from the Union of South Africa although in 1928 half came from Turkey. Turkey's best customer is now the Soviet Union.

\section{Preservation of an Old English Village}

WEST Wycombe is a seventeenth century English village which has recently come into the possession of the Royal Society of Arts and been reconditioned in such a way that its ancient beauty has been preserved and at the same time the amenities of present-day life have been introduced (Weir, W. and Hill, J. B. "Account of the Reconditioning of West Wycombe-Buckinghamshire." J. Roy. Soc. Arts, $81,893-910 ; 1933)$. In 1929, when the transfer was made, the local sanitary authority had already served notice of repair on some fifty cottages. The work of restoration has been carried out under the supervision of one of the authors, and the whole village is now let to tenants on agreement. Most of the property has been thoroughly reconditioned, inside and out, and the remaining twenty cottages have been partly reconditioned. Main water supply, main drainage, electric light in some cases, fenced gardens and wash-houses have been provided, and the interiors of many houses have been altered to give larger and better arranged rooms, with more conveniently placed doors and better lighting. The final result is a beautiful group of model cottages, showing what can be done for the preservation of old property as an alternative to its demolition. The series of photographs taken before and after reconditioning afford striking proof of the success of the experiment, and the brief accounts of the work carried out on different houses illustrate the diverse ways in which difficult problems were approached. The Royal Society of Arts is to be congratulated on the preservation of this old English village, together with the improvement in housing conditions that has been effected.

\section{The Exceptional Summer of 1933}

Aт the meeting of the Royal Meteorological Society held on December 20, Dr. J. Glasspoole read a paper entitled "The Exceptional Summer of 1933". The sunshine recorded over the British Isles exceeded the average in each of the four months JuneSeptember, tho mean excesses being 21, 17, 35 and 33 hours respectively. During this period many places in the south-east of England registered more than 1,000 hours of bright sunshine, nearly 200 hours more than usual. The total sunshine during these four months fell short, however, of that recorded during June-September, 1911. The mean temperature over the country generally exceeded the usual amount in each month February-October. July 1921 was as warm as July 1933 and these two Julys rank as the warmest on record. The mean temperature of August 1933 fell short of that of the Augusts of 1911 and 1899. The highest shade temperature recorded at Greenwich Observatory since 1841, namely, $100^{\circ} \mathrm{F}$., occurred on August 9, 1911, while August 1899 is the warmest calendar month on record for the British Isles as a whole. The outstanding feature of the summer of 1933 was the warmth of June-September. The total rainfall over the British Isles during the six summer months April-September was 13.8 in., which is less than that of any summer since 1870 , except 1870 with $12 \cdot 4$ in., 1921 with $13 \cdot 1$ in. and 1887 with $13 \cdot 7$ in. Rainfall was abundant in February and many reservoirs were overflowing at the beginning of April. Afterwards the slightly deficient rainfall of each month April-July, culminating in an unusually dry August, together with the loss by evaporation, resulted in a steady lowering of the level of the water in most reservoirs.

\section{Statistics of Unemployment}

AT the Royal Statistical Society's meeting on December 19, Mr. J. A. Dale read a paper on the "Interpretation of the Statistics of Unemployment". He suggested that there is a certain popular mis understanding of the figures, in that it is generally supposed that $2 \frac{1}{4}$ million unemployed are perma. nently out of work. The statistics which are most frequently quoted in public discussions do not, and from their nature cannot, disclose the way in which the actual personnel which they represent is constantly changing. It is a fact, however, that, although the total number of the unemployed may be about 21 million, the number of different persons unemployed in the course of a year is nearly six million, and a large part of the six million consists of persons whose unemployment is intermittent. Among those are to be included not only the 'temporarily stopped' workers and those whose employment is 'casual' but also many of the so-called 'wholly unemployed'. But there nevertheless remains a group whose unemployment is persistent and prolonged. Mr. Dale estimates that this 'hard core', represented by persons who have been unemployed for eight or nine months, number at most a million during the past year, the remaining five million being less unfortunate. There are many more in proportion suffering from prolonged unemployment in the depressed areas; about 100,000 of them were last employed in the coal mines, and the shipbuilding and iron and steel 